\title{
Analysis of the Khmer Walled Defensive System of Vimayapura (Phimai City, Thailand): Symbolism or Military Effectiveness?
}

\author{
Víctor Lluís Pérez Garcia ${ }^{1}$ (บิกตอร์ ยูอิส เปเรซ การ์เซีย) \\ Ph.D. in Archaeology, history teacher of the Generalitat de Catalunya, \\ Institut Tarragona, Tarragona, Spain \\ victorlluisperez@yahoo.com
}

\begin{abstract}
This article analyses the walled defensive system of the Khmer city centre of Vimayapura (modern Phimai, Thailand) to evaluate the theoretical level of military effectivity of both the walls and the moats against potential attackers, considering their technical characteristics and the enemy's weapons. We also study the layout of the urban enceinte, the constructive material, the gateways as well as weakness and strengths of the stronghold and the symbolic, monumental and ornamental functions in the overall role of the walls. Based on comparisons with similar cases, as well as in situ observations of the archaeological remains and a bibliographical research, our study reveals that the stonewalls were not designed primarily to resist military attacks. Instead, the army, the moat, and possibly the embankments and/or palisades would have been the first lines of defence of the city.
\end{abstract}

\section{Keywords}

fortifications - city walls - military architecture - Thailand - South-East Asia

1 Member of the "Seminary of Ancient Topography" archaeological research group at Universitat Rovira i Virgili of Tarragona (Catalonia). www.victorperez.webs.com. 
บทคัดย่อ

การวิเคราะห์ระบบกำแพงเมืองวิมายปุระ (เมืองพิมาย): การแสดงสัญลักษณ์หรือ ประสิทธิภาพทางการทหาร

บทความนี้วิเคราะห์ระบบกำแพงเมืองที่ใจกลางเมืองวิมายปุระ (หรือพิมายในปัจจุบัน) ซึ่งเป็น เมืองในอารยธรรมเขมรเพื่อประเมินประสิทธิภาพทางทหารของกำแพงและคูเมืองในการป้องกัน ภัยจากผู้รูกราน รวมถึงพิจารณาลักษณะเฉพาะตัวทางเทคนิคและอาวุธยุทโธปกรณ์ของข้าศึก นอกจากนี้บทความยังได้ศึกษาแผนผังโครงสร้างของกำแพงเมือง วัสดุที่ใช้ก่อสร้าง เส้นทางเข้า ออก รวมทั้งจุดอ่อนจุดแข็งของที่มั่น และบทบาทหน้าที่ของกำแพงโดยรวมในเชิงสัญลักษณ์ ใน เชิงการเป็นอนุสาวรีย์ และในเชิงการเป็นเครื่องประดับตกแต่ง ซึ่งเมื่อนำไปเปรียบเทียบกับกรณี ศึกษาที่มีลักษณะคล้ายกัน ประกอบกับการสังเกตภายในแหล่งโบราณสถานและการวิจัยเอกสาร พบว่า กำแพงหินนี้ไม่ได้ถูกออกแบบมาเพื่อใช้ต่อต้านการโจมตีจากกำลังทหารฝ่ายข้าศึกเป็นหลัก แต่มีกองทัพ คูเมือง และอาจจะรวมถึงคันดินหรือรั้วเป็นแนวตั้งรับแนวแรกของเมือง

\section{Introduction}

Vimayapura was an ancient Khmer city founded during the reign of Jayavarman VI (1080-1107 AD) at the present town of Phimai (Figure 1), in the Khorat Plateau or Upper Mun River Valley, which became territory of Thailand after the conquest by Ayutthaya at beginning of the $15^{\text {th }}$ century. ${ }^{2}$ Vimayapura was created as the provincial capital of the Khmer empire when the attention of the kings focussed on this region at the end of the $11^{\text {th }}$ century, around one hundred years after seizing it from the previous Mon occupants. ${ }^{3}$ At that time, the Mahidhapura dynasty (Jayavarman VI - Suryavarman II) wanted to establish a power base to the north of the Dang Raek mountain range (Dagens 2003, 30; Hendrickson 2007, 196-97) and construct a roadway connecting it to the capital of the empire, Yashodharapura (Angkor). ${ }^{4}$ Furthermore, King Jayavarman VI

2 The city is located at 15.28 degrees of latitude North, 102.50 degrees of longitude East and 155 metres above sea level.

3 Suryavarman I (1002-1050) let military expeditions up the valley of the Chao Phraya (to Lopburi) in the west, to the northern slopes of the Dang Raek Mountains (Thailand) in the north, into the Mekong basin (Laos) to the east and to the Gulf of Siam in the south (Chihara 1996, 140). However, during the $7^{\text {th }}$ and 8th centuries AD the Upper Mun River Valley already formed part of the Chenla Kingdom or Confederacy, the political entity predecessor of the Khmer Empire. Moreover, the Khmer King Rajendravarman II (944-968) already had some power in the Khorat Plateau (Miksic and Goh 2017, 391). A few kilometres from Phimai there is the previous Khmer temple of Phnom Wan, built over the $9^{\text {th }}$ and $11^{\text {th }}$ centuries (Freeman 1998, 64-69).

4 These roadways were the physical manifestation of the political and economic expansion of the Khmer empire across the Indochinese peninsula (Hendrickson 2010a, 480-96). 
was born in the region of modern Phimai (Higham 2003, 107) and the city was strategically located on an ancient trade route from Khorat to the Chao Phraya Delta.

The city of Vimayapura centred around a Mahâyâna Buddhist temple (nowadays called Prasat Hin Phimai), in the same way as other Khmer cities centred around important Hindu sanctuaries (Freeman 1997, 1998; Jacques and Lafond 2004, 2007; Seidenfaden 1923, 1-19). The temple of Phimai, especially its central tower, was very likely the prototype of Angkor Wat (Coe 2003, 116; Miksic and Goh 2017, 391), built during the $12^{\text {th }}$ century in the same architectural style. The ruins, one of the largest Khmer complexes, were surveyed and described for the first time in 1901 and 1907 by the French archaeologists Etienne Aymonier (1901, 118-24) and Lunet de Lajonquière (1907, 278-98) and in 1936 they became officially protected by the Thai government. ${ }^{5}$ Between $1964-1969$ they were restored using the anastylosis technique (Crocker 2006, 114-122; Pichard 1976) and in the last decades several archaeological excavations were undertaken in the temple (Talbot and Janthed 2001, 179-94).

In addition to the sanctuary, inside the city walls we can also find old ponds ${ }^{6}$ (barays) of small and middle sizes and one brick funerary stupa (chedi) which belongs to the late Ayutthaya period $\left(18^{\text {th }} \mathrm{c}\right.$.), during the Thai rule of Phimai. Unfortunately, we do not have much information about the domestic buildings of the Khmer city, since the urban area remains densely occupied and no archaeological excavations have been undertaken outside the temple site. Moreover, we should keep in mind that in the past Khmer people extensively used non-durable materials in the construction of their houses and other structures, which had perished long ago without leaving any trace. ${ }^{7}$

Unfortunately, the city walls have not been dated stratigraphically through the archaeological method of excavation preventing further analysis of the recovered materials. However, Vimayapura is mentioned in several inscriptions: one in the year 1082 and another from the end of the $12^{\text {th }}$ century (Freeman $1998,71)$. Thus, we can assume that the urban enceinte had already been erected at the beginning of the reign of Jayavarman VI or, if we consider that they were built by Jayavarman VII (1181-1218) as a part of his vast monumentalising program of the provinces, ${ }^{8}$ we can imagine the previous existence of moats and a palisade or earth wall. The practice of reconstruction in more solid materials, as well as the addition of structures to an older complex, was not

5 Government Gazette, volume 53, section 34, dated $27^{\text {th }}$ September 1936.

6 The modern names of those barays in the Thai language are Sra Kaew, Sra Phlung and Sra Khwan.

7 According to ancient Khmer belief, stone and likely brick were reserved as building materials for the homes of gods and not for people (Foucher 1903, 178-79).

8 This hypothesis is suggested by the reuse of stone pillars in the West Gate (Figure 17). 


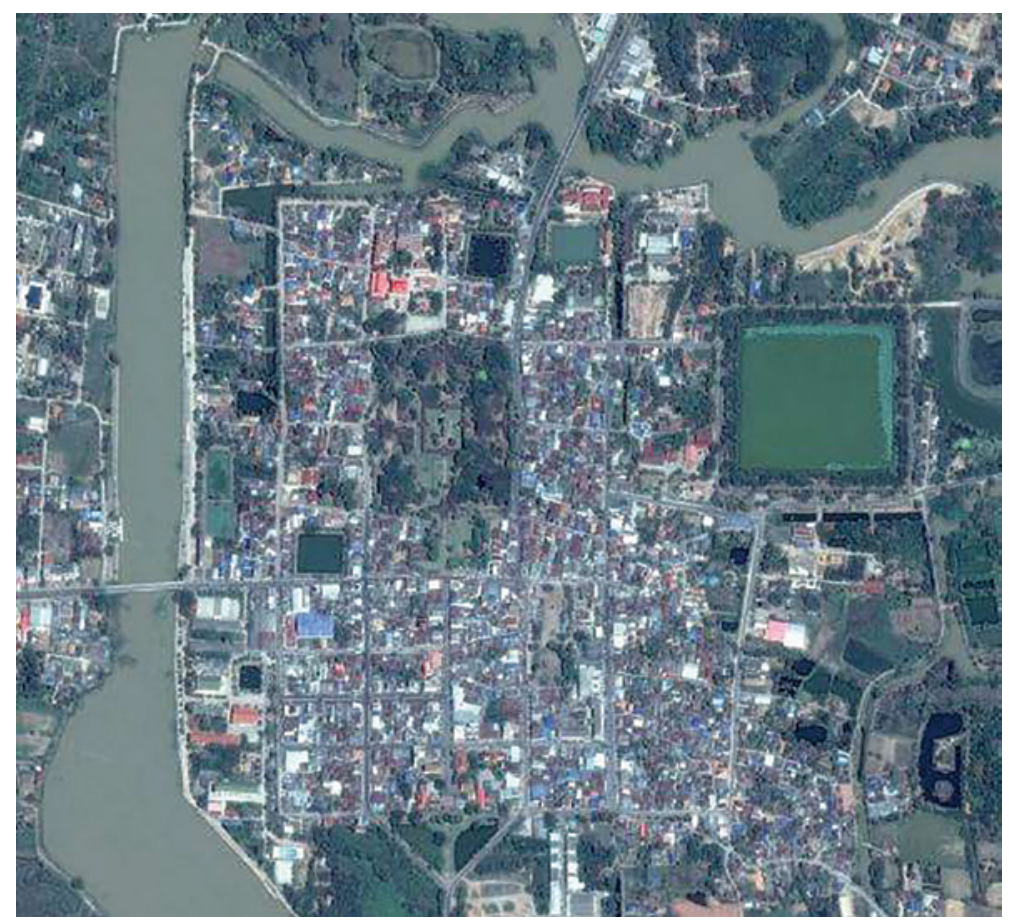

FIGURE 1 Satellite image of modern Phimai (Google Earth)

unusual in Khmer architecture. For instance, archaeological excavations at the temple site of Phimai reveal that, at the end of the $11^{\text {th }}$ century, Jayavarman VI replaced an old brick temple with the existing sandstone tower-sanctuary (prasat) (Talbot and Janthed 2001, 190-91) and comparative style studies and the epigraphy inform us that several more structures were added to the religious complex in the $12^{\text {th }}$ century and also at beginning of the $13^{\text {th }}$, in the time of Jayavarman VII (Manavit and Sangwan n.d.).

\section{$2 \quad$ Layout of the Urban Enceinte}

The city wall has a perfect rectangular shape of 565 metres (north and south sides) by 1030 metres (east and west sides). ${ }^{9}$ Although most of the fortified

9 In 1901, Aymonier wrongly calculated that the urban enceinte of Vimayapura was 1100-1200 metres x more than 700 metres (Aymonier 1901, 119). A few years later Lunet de Lajonquière estimated that it was around $1100 \times 600$ metres (Lunet de Lajonquière 1907, 290). Nowadays there is still a certain degree of confusion with regard to the exact numbers in modern publications, especially informative but also academic: thus, some authors state that the north and south sides are 665 -metre long, instead of 565 metres. The correct size, checked 
perimeter has not been preserved ${ }^{10}$ we can deduce the rest of the original path from four indices:

1) The location and orientation of the gateways, as well as the direction of the remaining walls, ${ }^{11}$

2) The path followed by the moats — which mark the external limit of the enceinte-,

3) A comparison with other parallel cases, like the city walls of Angkor Thom, designed also with rectilinear walls and a rectangular shape,

4) The survival in the modern town of Phimai of the ancient orthogonal city plan with a grid layout, composed of rectilinear streets and regular blocks of houses, ${ }^{12}$ the same as in other Khmer cities such as Beng Mealea and Preah Khan of Kompong Svay, amongst others (Evans 2016, 164-75).

The analysis of all these clues allows us to reconstruct the whole path followed by the city walls of Vimayapura, connecting the few remains left through the missing parts. This allows us to highlight several observations and reach some conclusions, regarding the size, shape and orientation of its layout.

At first glance, we may have the impression that Vimayapura was not big, especially in comparison with other Khmer urban enceintes like those from Angkor (4 X 4 kilometres) and Preah Khan of Kompong Svay (circa $5 \times 5$ kilometres). However, those should be considered as exceptions, because one was the capital of the most powerful empire of its time in the Indochinese peninsula and the other was a unique case, the largest rectilinear enclosure complex in mainland Southeast Asia. ${ }^{13}$ Moreover, if we take a look at the common sizes of the

personally analysing aerial photographs and satellite images from Google Earth, appears in the English official tourist brochure and guidebook "Phimai Historical Park" given / sold to the visitors at the entrance of the temple (Manavit and Sangwan n.d., 26), amongst other books and articles.

10 Only three sections survived: around 50 metres in the South, 20 metres in the North and 20 metres in the West.

11 It seems that, until 1907 (Lunet de Lajonquière 1907, 289, Fig. 94), was the preserved section of the wall extending from the North Gate to the North-West corner, although we ignore in which conservation status. However, today only a few metres of wall at each side of three gateways are visible.

12 Hirotomi et al. (2009, 2399-2405) studied the spatial formation of townhouses in Phimai. The regular distribution of buildings and streets, easy to observe in satellite images, remind us of emblematic Japanese cases like Nara and Kyoto (Pérez 2016a, 1-23).

13 Surprisingly, a provincial capital had a bigger enclosure than the imperial capital, considering that both Yashodharapura from the $9^{\text {th }}$ and $11^{\text {th }}$ centuries could have had a square of 4 kilometres per side (Ewington 2008) and Angkor Thom one of 3 kilometres per side (Pérez 2016b, 239-40), while Preah Khan of Kompong Svay (Bakan) had a square plan of almost 5 kilometres per side (Mauger 1939, 197-220; Hendrickson et al. 2010; Hendrickson and Evans 2015, 644-64). 
urban enceintes of other Southeast Asian countries, we will realise that the $1030 \times 565$ metres of Vimayapura may have been adequate for a centre of regional importance. ${ }^{14}$ We cannot forget either, that few Khmer settlements were properly walled with laterite and stone at the peak moment of the empire.

Kings never decided arbitrarily or at their whim the location of cities, their orientation and their layout. The plan of the ideal Khmer city was inspired by the model of the Khmer temples, which were based on Hindu cosmology (Stuart-Fox and Reeve 2011, 105-138). It should have a perfect quadrangular shape, walls with four gates in the middle of each side and an organised internal layout resembling a mandala, with the city temple in the centre and its main sanctuary inside it, with a tower shape which represents the mythological Mount Meru, the sacred axis mundi, separated by successive concentric walls. At the same time, this concrete representation of cosmology in city planning was based on the religious and political idea of the "god-king" (devaraja), which considers monarchs as incarnations on the Earth (avatars) of Shiva, Vishnu or Buddha (Chihara 1996, 25-26, 30-34).

Although these beliefs and rigid ways of designing cities and religious complexes were imported from India, ${ }^{15}$ actually the Khmers brought to their country texts with detailed indications and exact proportions of how ideal buildings should be (vatu-shastras), not real models of city planning based on existing walled settlements to be copied. The Indians rarely planned their cities as microcosmic replicas of the divine macrocosm, ${ }^{16}$ something the Khmers liked to put into practice, starting with their royal capitals and following with the provincial and regional centres of power. Moreover, the pre-eminent role and central position of the main temple in the Khmer urban design lead us to interpret the plan of cities like Vimayapura under the concept of "temple-city"

14 The size of Vimayapura is similar to other Khmer provincial centres (Boisselier 1952, 187226; Jacques and Lafond 2004, 2007), like Beng Mealea (1025 x 875 metres, Freeman and Jacques 2008, 220), just a little smaller than Banteay Chmar (1900 x 1700 metres), and not much different from the average Southeast Asian royal capital with a quadrangular shape: the Champa Cha Ban or Vijaya citadel (in Canh Tien, Binh Dinh, with $1400 \times 1100 \mathrm{~m}$ ), from the $11^{\text {th }}-15^{\text {th }} \mathrm{c}$. (Phuong 2012, 75-9), the Thai Sukhothai (1810 x $1400 \mathrm{~m}$ ), from 1238-1438 (Rooney 2008, 71) and Chiang Mai (1750 x $175^{\circ}$ metres), built in 1336-1355 (Freeman et al. 2006).

15 The imperial expansion of the Chola dynasty ( $3^{\text {rd }}$ c. BC-1279 AD) helped to spread the influence of Indian civilisation across the whole of Southeast Asia during Khmer times (Kulke et al. 2009).

16 Notable exceptions are the quasi-square walled cities of Jaugada and Kalinganagara in Shishupalgarh (Orissa), dated from $3^{\text {rd }}$ and $2^{\text {nd }}$ centuries BC (Yule and Böhler 2004, 15-29; Patra 2007, 44-47). 
or "sacred town". All this symbolism determined several aspects of the fortified walls, such as the shape, size, proportions and exact location of the gateways.

As for the orientation of both the urban walls and the temple enclosure in relation to the cardinal directions, it is important to highlight a peculiar characteristic uncommon in other Khmer cities and sanctuaries: instead of facing the East - that is, where the sun rises every morning —, the main gates of Vimayapura and its temple were constructed facing Southeast or, to be more precise, a direction between South and Southeast. In consequence, the whole enceinte as well as the religious structures within it followed the particular axis NNW-SSE ${ }^{17}$ (Figure 2).

A variation in the orientation of ancient Buddhist and Hindu temples according to the moment of construction has been observed often in Thailand as well as in other East Asian countries. This phenomenon has been explained by the constant drift of the geomagnetic field of the Earth over time (Iyemori et al. 2011, 139-49). However, we can assume that the reason for the deviation in the case of Vimayapura is not accidental nor linked to geomagnetism but intentional: if we leave the city towards SSE direction, after around 300 kilometres ${ }^{18}$ we will arrive at Angkor. Actually, there was an ancient road following this route, with a well-organised network of rest-houses (vahni-grihas) and hospitals (arogyasalas) along its way, which became the most significant of the Khmer empire. Although most of these buildings were erected in stone around one hundred years after the foundation of Vimayapura (under Jayavarman VII's rule, 1181-1218), the route probably started to be used much earlier, at least from the origin of the city. ${ }^{19}$

17 Amongst the 229 Khmer temples from East Thailand (Isan region), only Phimai and Ta Muen Thom, both dated at the end of the $11^{\text {th }} \mathrm{c}$., were orientated towards SSE, respectively $20^{\circ}$ and $8^{\circ}$ from cardinal South (Mollerup 2012, 149-51).

18 There is no consensus on the exact length of the ancient road that connected both cities: some authors talk about 260 or 268 kilometres (Hendrickson 2010b, 98 ), while many others mention 225 kilometres (Albanese 2005, 266; Freeman 1998, 73; Higham and Thosarat 2012, 247; Miksic and Goh 2017, 391). According to Google Maps, the shortest way to go by path from Angkor until Phimai is around 310-kilometre long (150 kilometres from Angkor to the present Thai-Cambodian border and almost 160 to Phimai), and 370 kilometres by paved roads. Although the estimated route in Khmer times was probably straighter than the modern one, we do not think it could have been much shorter than 300 kilometres. Thus, the number of 268 provided by the expert in ancient Khmer roads, Hendrickson, is the closer one.

19 According to new studies, Jayavarman viI was not the creator of the whole Khmer network of royal roads but he modified, improved and monumentalised a pre-existing system formalised during the reigns of Suryavarrnan l (1002-1050) and Suryavarman II (11131150 ). It its even probable that a previous trade route had been used since the $9^{\text {th }}$ century (Hendrickson 2010a, 480-96; 2010b, 87). 
Furthermore, there is a distinction between Vimayapura and other Khmer regional capitals and important temples with direct connection by road with Angkor. The cities with sanctuaries of Beng Mealea (Evans 2016, 164-75) and Preah Khan of Kompong Svay (Hall et al. 2016, 53-63; Hendrickson et al. 2010; Hendrickson and Evans 2015, 644-64) (Cambodia), for instance, have their main gates orientated towards East and North-East respectively instead of facing Angkor, located in the West. ${ }^{20}$

All these facts indicate that Vimayapura was designed with a specific orientation towards SSE instead of East to give effect to its special position and importance in its relationship to the imperial capital Yashodharapura (Angkor). However, there is still a slight deviation from this precise direction: instead of pointing 35 degrees east of south (towards Angkor), the axis of the city points 20 degrees. This can be explained by the geographical constraints imposed by the river courses (Freeman 1998, 73).

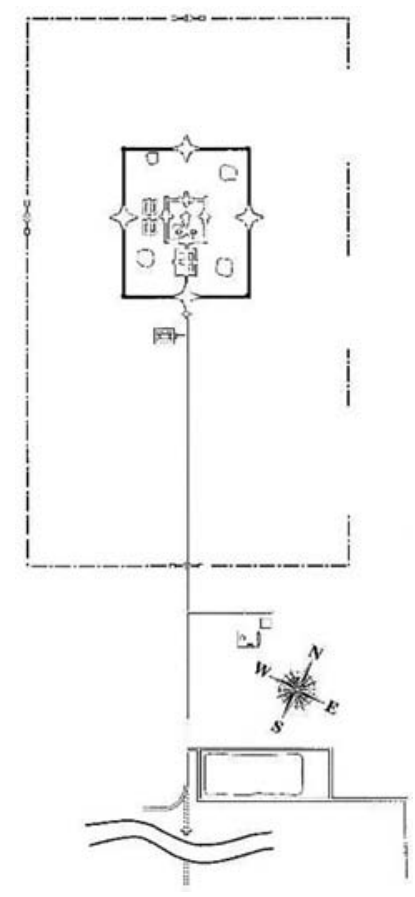

FIGURE 2

Plan of Vimayapura with the Khmer city walls and the temple (Manavit and Sangwan n.d., 22)

20 Some authors think that the reason Preah Khan of Kompong Svay has an axis NE-SW instead of N-S or E-W is because it was orientated to the moon rising at the maximal northern standstill (Magli 2017, 1-17). 


\section{Constructive Material and Technical Characteristics}

Stone blocks were mainly placed in the most important parts of the urban enceinte, that are the monumental gateways, symbols of city prestige as well as vulnerable points, due to their function as accesses, that needed additional reinforcements, including a more solid, resistant and durable material. For the rest of the perimeter, for the long sections of rectilinear walls that connect the four gates, softer blocks of laterite were used.

The type of sandstone used in Phimai and other Khmer monuments from the Khorat Plateau is lithic sandstone, composed of fine-grained quartz and rock fragments. Specifically, the colour found in the city walls, gates and temple of Vimayapura is reddish-brown, almost pink. Unlike Khmer settlements in the alluvial plain of the Chao Phraya basin (Lopburi, Sukhothai, Sisatchanalai, Kanchanaburi), where laterite was a more common material for construction, in the region of Vimayapura it was not difficult to obtain sandstone from local quarries, where it was supplied mainly from the Khok Kruat rock formation (Uchida, Ito, and Shimizu 2010, 550-74).

Laterite is a type of highly compacted and cemented clay soil rich in iron oxides and aluminium, formed in hot and humid tropical areas, which hardens into solid rock in contact with the air and becomes resistant to atmospheric conditions, being therefore suitable as a construction material and easy to cut into brick-shaped blocks. ${ }^{21}$ This natural material was broadly used in South Asia, from India to the Indochinese Peninsula, throughout history, especially in ancient Khmer architecture, due to its abundance and its ease of quarrying (Watsantachad 2005). Although laterite is not technically a stone, it resembles a rock, given its aspect, composition and solidity. The original colour of the blocks from Phimai at the moment of construction seems to have been dark-reddish ochre; however, with time and pollution, they have become darkbrown and grey. The blocks of laterite have a rough texture and tiny irregular holes naturally present in the material, which at first glance recall the appearance of volcanic stone and they are useful for attaching an external white stucco coating.

According to traditional Khmer constructing technique, in the city walls of Vimayapura both sandstone and laterite were cut in rectangular parallelepipeds. All the blocks were laid in imperfect horizontal rows. Their sizes were irregular: they varied roughly from 30 to 40 centimetres in height and in many

21 The chemical formation process named laterisation, consists of an intensive and longlasting weathering or leeching of the underlying parent rock. 
cases, they had a length of around 1 metre, although in other cases they were much shorter. The curtain walls were solid, without any internal filling of earth, brick or rubble. Actually, they were quite narrow, approximately one metre wide in the centre, and two metres and a half in the base.

The rectilinear sections of the urban enceinte were not simple vertical walls but had some architectural decorative elements which resemble the enclosure walls from some Khmer temples, albeit less ornamental. In the lower part, walls were raised on basements, while in the upper part, although not at the top, a cornice protruded a few centimetres from the wall. Basements consisted of two steps, the first higher than the second, of about one metre high in total and narrower than the basements of temple enceintes. The cornice was composed of two rows of blocks with carved strips.

No remains have been preserved of the top part. We imagine the walls were originally crowned with stone pinnacles that in case of siege could be used as merlons, in addition to their decorative function. It could be a kind of parapet or battlement with an artistic crenellated appearance, probably inspired by some religious enceintes. ${ }^{22}$ The preserved height of the curtain walls was above 3-3.5 metres, probably reaching 4 metres with the upper elements nowadays $\operatorname{lost}^{23}$ (Figure 3).

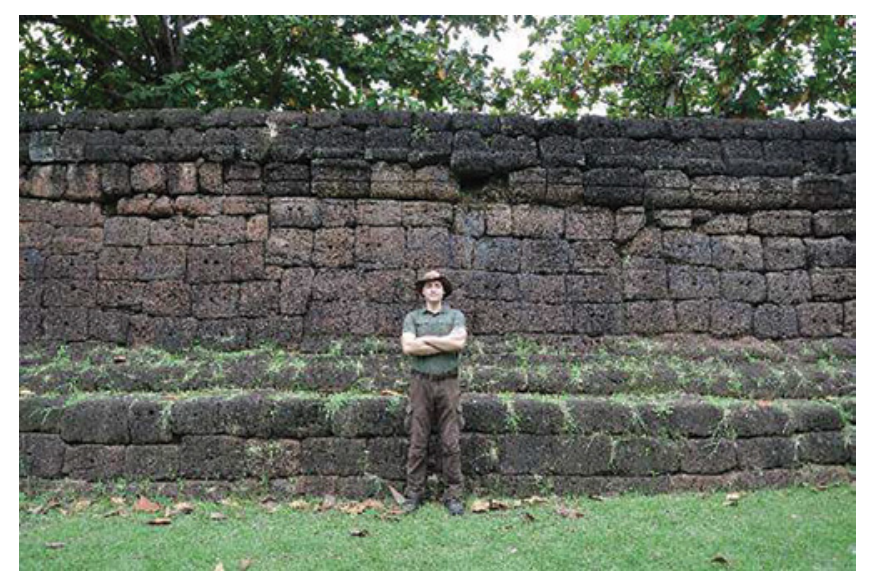

FIGURE 3 Laterite walls from the South side, with a 1.78 metre tall man in front of it for size reference (author's photo, 2017)

22 In the nearby Khmer temple Muang Tam (contemporary of Vimayapura), for instance, there are some stone pinnacles preserved at the top of the outer walls (Freeman 1998, 116-23).

23 In 1907, Lunet de Lajonquière calculated that the city walls were originally 4-metre high (Lunet de Lajonquière 1907, 290). 
Many blocks have several circular holes with a diameter of 3-4 centimetres, both in the long and narrow sides (Figures 4 and 5). Ancient Khmers made these to facilitate their transportation and especially their placing during construction, by inserting within them wooden sticks in horizontal position or pegs in the vertical holes (Dumarçay and Royère 2001, 15; Watsantachad 2005, 67 , Fig. 1.30). Having clarified their main purpose, we propose another secondary use in case of need, for which we do not have any certainty or proof. In other countries, sometimes putlog holes in fortresses (city walls, castles and forts) were used not only to support temporary wood scaffolding during the construction of the walls but also in times of battle they supported hoardings or elevated platforms for the defenders. Despite the existence of those types

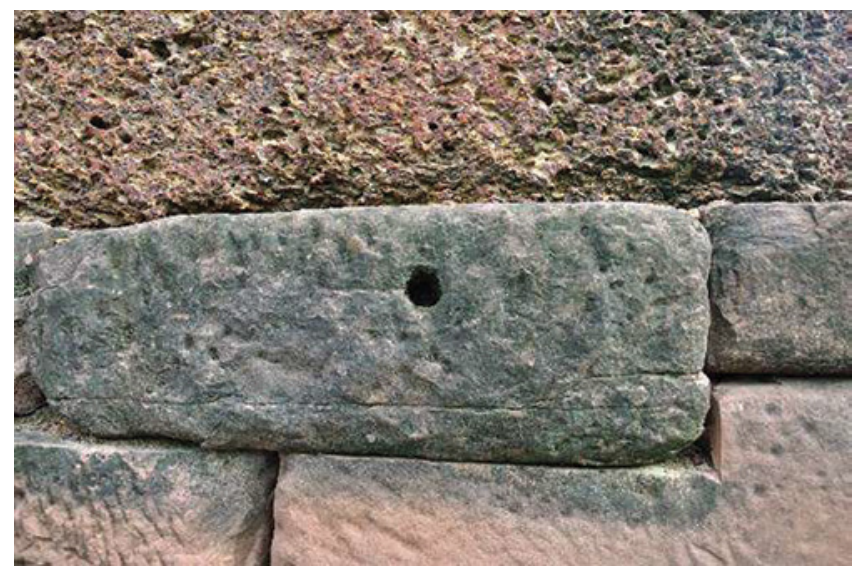

FIGURE 4 Circular hole in a sandstone block (author's photo, 2017)

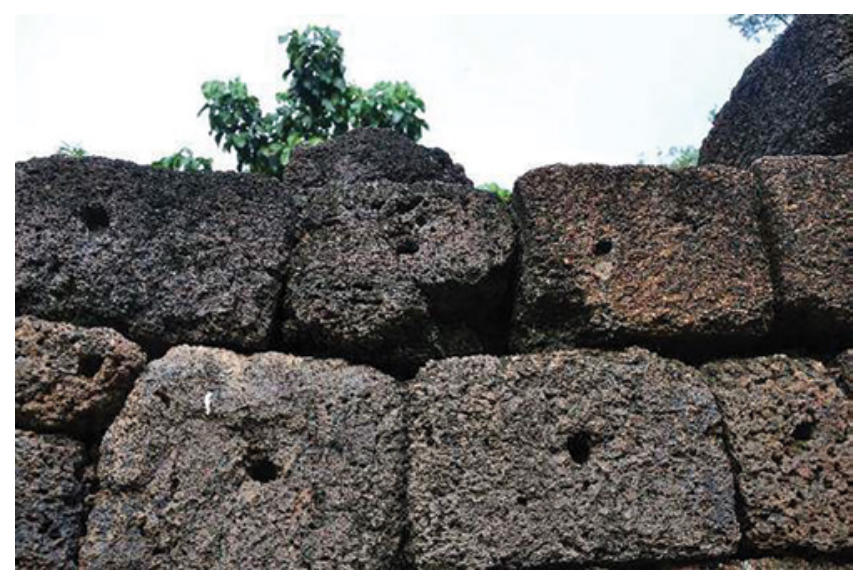

FIGURE 5 Circular holes in laterite blocks (author's photo, 2017) 
both inside and outside the enceinte of Vimayapura and both in the upper and lower rows of blocks, we wonder whether in cases of emergency, under attack from enemy troops which managed to cross the moat and reach the walls, they could also be used with this defensive aim. After all, it is very convenient to have so many holes with the size of wooden poles and bamboo spread throughout the walls, close enough to each other and following fairly horizontal straight lines.

\section{$4 \quad$ City Gates}

The urban enceinte had four gateways, located in each of the cardinal directions. ${ }^{24}$ Nowadays no remains of the East Gate are left since it seems to have disappeared a long time ago. The rest of the gateways are currently in the process of restoration and some of them even need the support of internal beams and metal scaffolding to prevent them from collapsing. None of them is used anymore as a means to access the city centre by people in cars but they have been separated from the traffic and protected from human activity inside small lawn areas.

The South Gate, called "Victory Gate" (Pratu Chai in Thai language), was the most important one of Vimayapura (Figures 6, 7 and 8). It is connected to the main entrance of the temple through Chom Suda Sadej Street and it faced towards the imperial capital Yashodharapura / Angkor Thom. Indeed, there are still traces of the ancient road that led from this gateway. As for the North Gate, known as the Ghost or Spirit Gate (Pratu Phi in Thai), it is precisely situated in the middle of the north section of the wall (Figures 9 and 10).

The West and East gateways were not located exactly in the centre of the long sides of the rectangular urban enceinte but were closer to the north. ${ }^{25}$ The reason for this is the particular position of the temple enclosure in the northern half of the city and the will to link with streets (nowadays called Suriya Atsadong and Samai Ruchi) the west and east gates of the religious area with the respective city entrances. The West Gate is known as Stone Gate (Pratu Hin, Figures 11, 12 and 13).

24 Although we will refer in this article to the city gateways as north (N), south (S), east (E) and west $(\mathrm{W})$ gates, their exact orientation are at the secondary inter-cardinal directions between the north and north-west (NNW), south and south-east (SSE), east and northeast (ENE), west and south-west (WSW), respectively.

25 Thus, the western and eastern walled sides were divided into two sections of approximately $40 \%$ and $60 \%$ of the total length. 


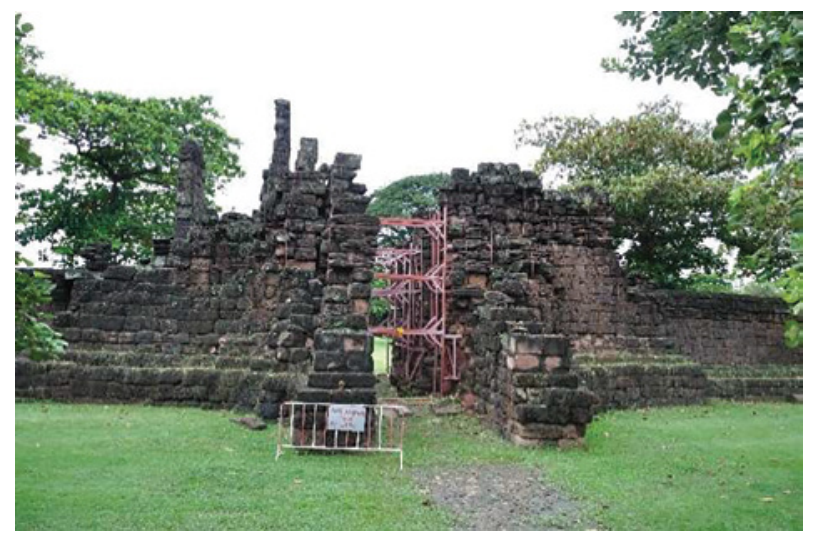

FIGURE 6 Front view of the South Gate, from inside the town (author's photo, 2017)

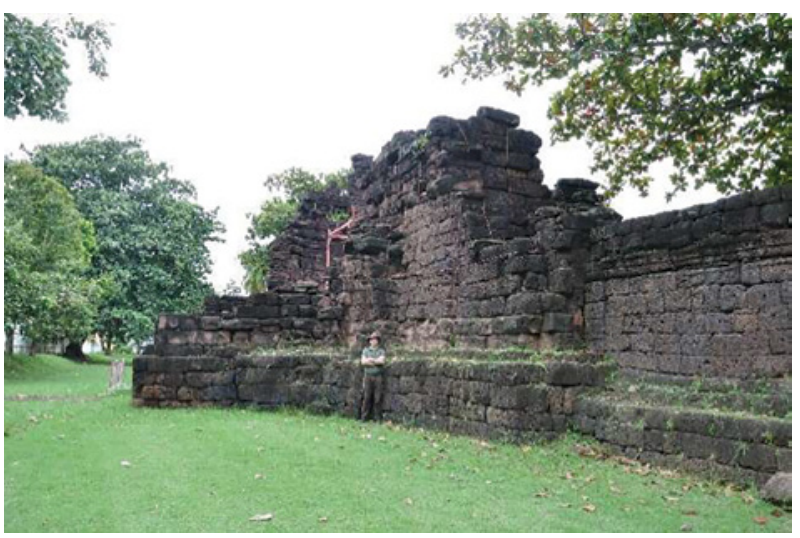

FIGURE 7 The South Gate, with a 1.78 metre tall man in front of it for size reference (author's photo, 2017)

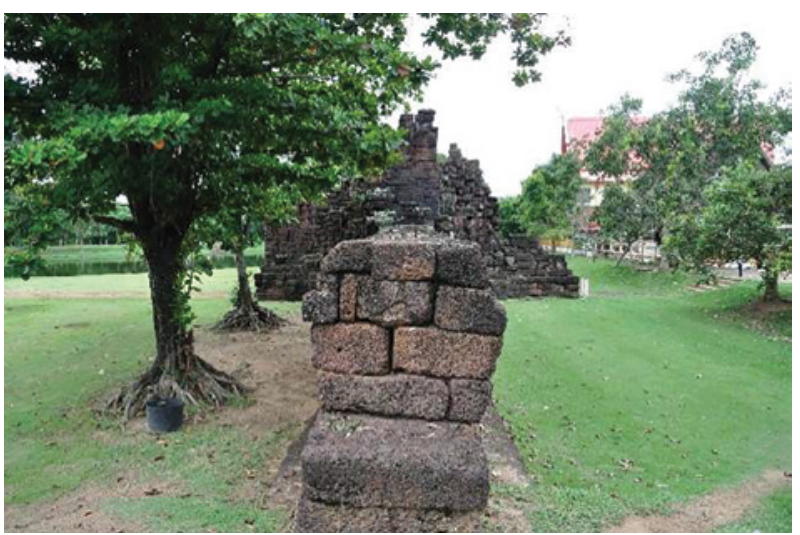

FIGURE 8 Side view of the South Gate and a section of the wall (author's photo, 2017) 


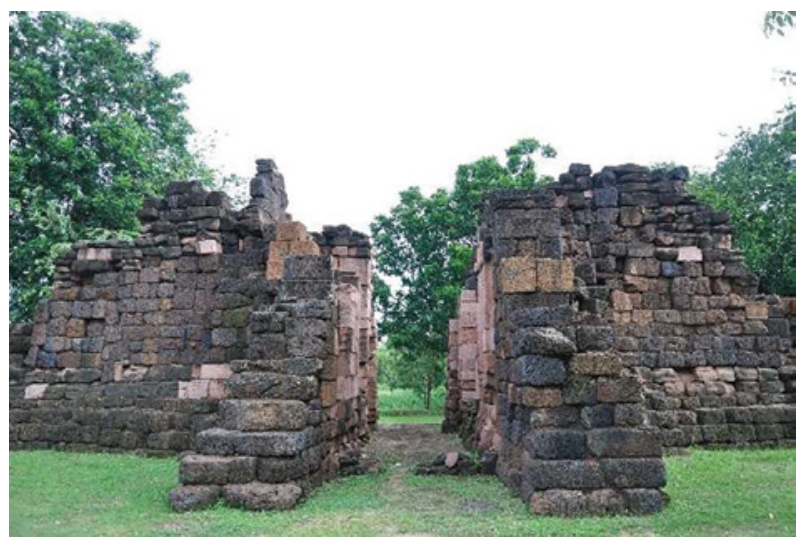

FIGURE 9 Front view of the North Gate from inside the town (author's photo, 2017)

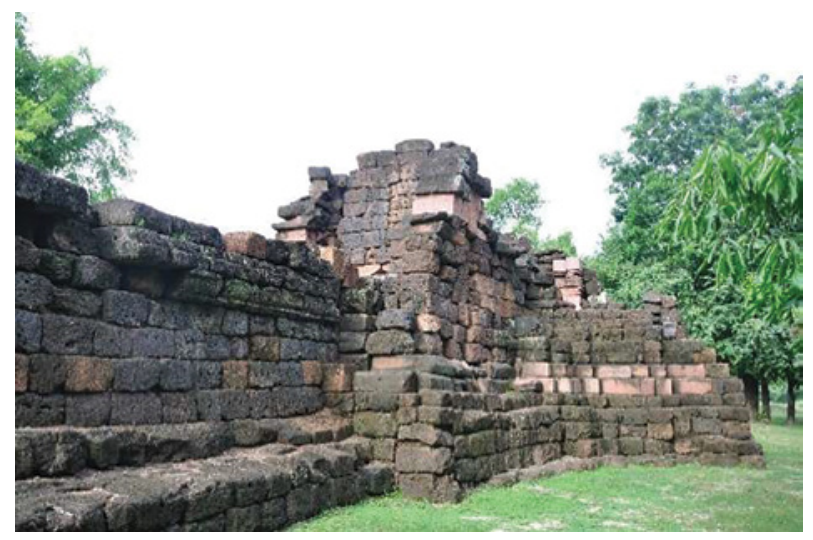

FIGURE 10 View of the North Gate from outside the town (author's photo, 2017)

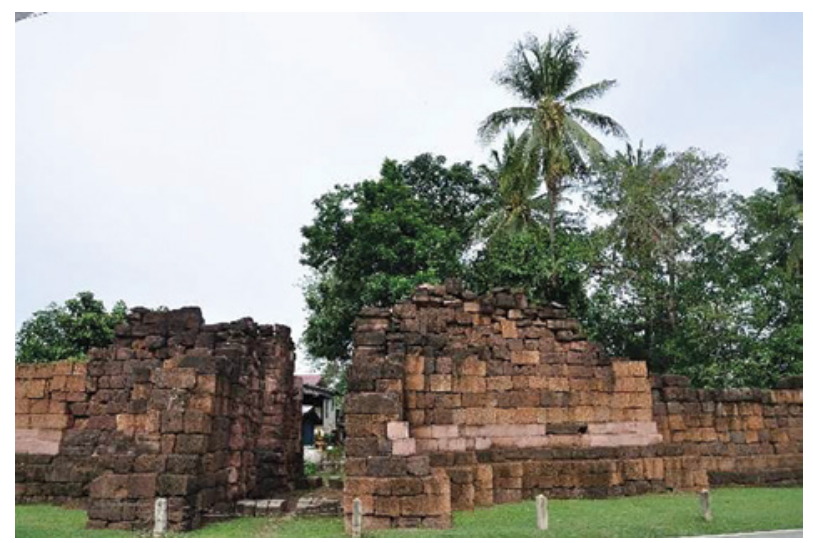

FIGURE 11 Front view of the West Gate from inside the town (author's photo, 2017) 


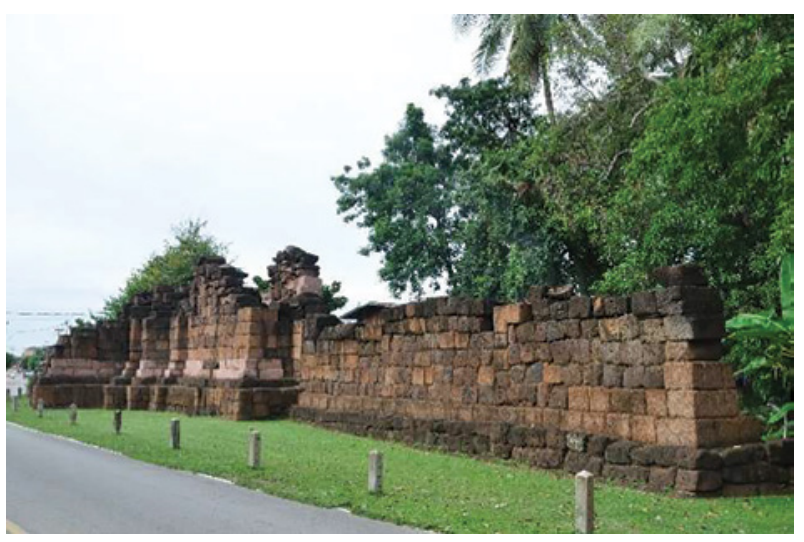

FIGURE 12 View of the West Gate from inside the town (author's photo, 2017)

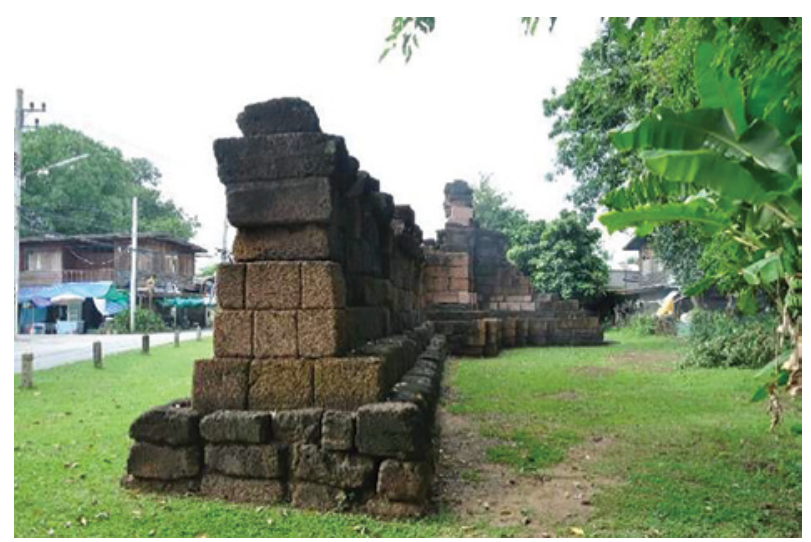

FIGURE 13 Side view of the West Gate (author's photo, 2017)

In general, these gateways have much less decoration than the gates of the religious complexes, something that we had already expected not to see so much in a city fortress. However, it was common in Khmer architecture that the gates of urban enclosures (called gopura in Sanskrit) were monumentalised in a particular way, including having a height of wall superior to the rectilinear sections of the perimeter. Thus, the size of the gateways of Vimayapura was sufficient for a royal elephant to enter; we calculate the width was approximately 2.5 metres, the length of the passageway almost 12 metres and the preserved height 6 metres, excluding the vaults and towers (Manavit and Sangwan n.d., $\left.25^{-26}, 81-82,87-88,93\right)$. As a comparison we note that the passageways of Angkor Thom are 3.5-metre wide, 16-metre long and 7-metre high (Pérez 2016b, 239). 
The same as the gates of many Khmer towns and temples, including Prasat Phimai, those from the urban enceinte of Vimayapura had a cruciform plan (Figure 14). They form a Greek cross, composed of a passage perpendicular to the enclosure walls flanked by two side chambers with the stone floor elevated around one metre from the level of circulation. ${ }^{26}$ Each of those chambers was divided into three smaller rectangular spaces, with doors between them, except for the first one which was open (Figures 15, 16 and 17). They would have been used as guard posts, to control the passage of people, carriages, animals or goods inside and outside the city centre.

The jambs of the doors still have, carved in stone, the corresponding vertical frames for installing the heavy wooden panels, nowadays gone (Figure 18). Moreover, on the floor of the passageways there are two rows of transversal stones, about one metre wide and 30 centimetres high, exactly in the points where the doors closed. Besides this function, these elements could have served for hindering the pace of those who crossed the gates, mounted or on foot, thus increasing the security of the control post.

The gates were originally covered with the characteristic corbel or false vaults used by the ancient Khmers and crowned with tower-like decorative structures, none of them preserved. Although it is tempting to imagine gigantic stone faces similar to those from Angkor Thom or Banteay Chmar (Sharrock 2015), unfortunately we do not have any conclusive data regarding this possibility. Nevertheless, we should remember that in Khmer art those giant faces

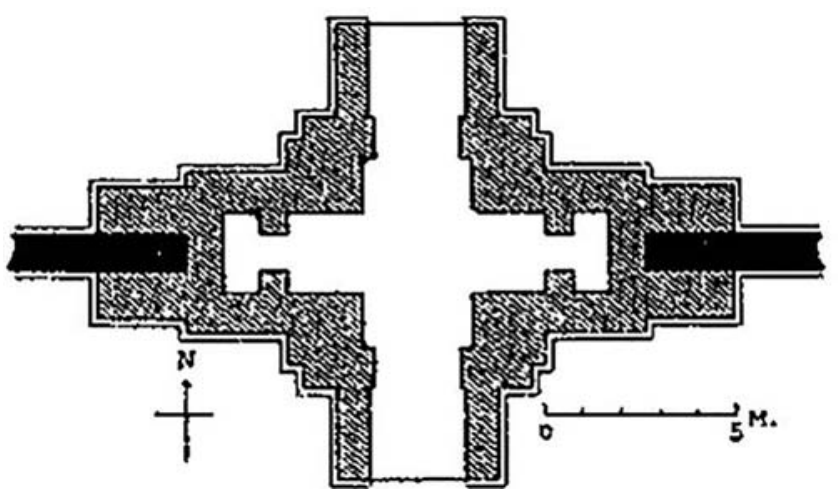

FIGURE 14 Old plan of the North Gate of Vimayapura (Lunet de Lajonquière 1907, 290). Although the proportions are correct, each one of the side chambers should be divided into three spaces instead of two

26 They correspond to the second type of Khmer monumental gates (gopura) classified by Albanese $(2006,47)$, according to their plan and general structure. 

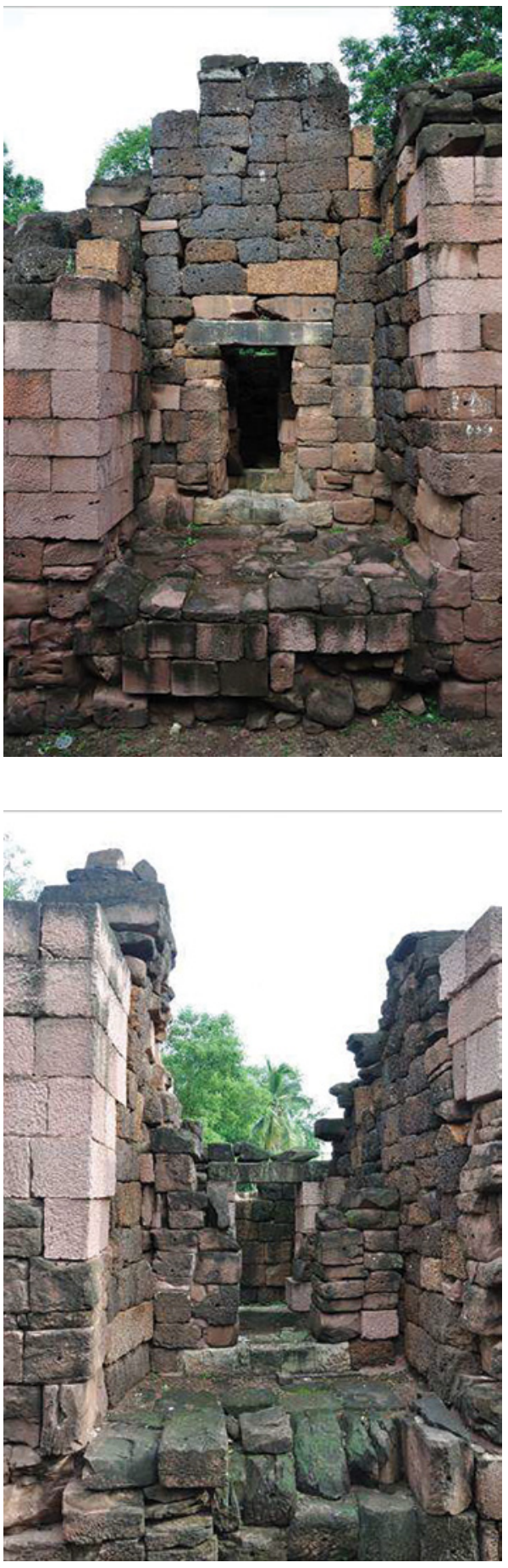

FIGURE 15

One of the side chambers of the North Gate divided into three spaces (author's photo, 2017)
FIGURE 16

One of the side chambers of the West Gate divided into three spaces (author's photo, 2017) 


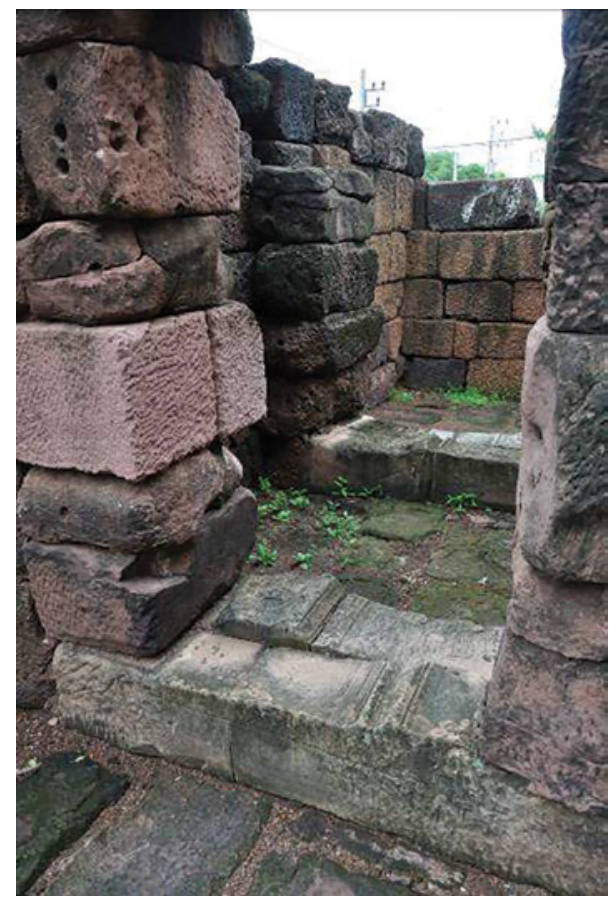

FIGURE 17

One of the side chambers of the West Gate divided into three spaces (author's photo, 2017)

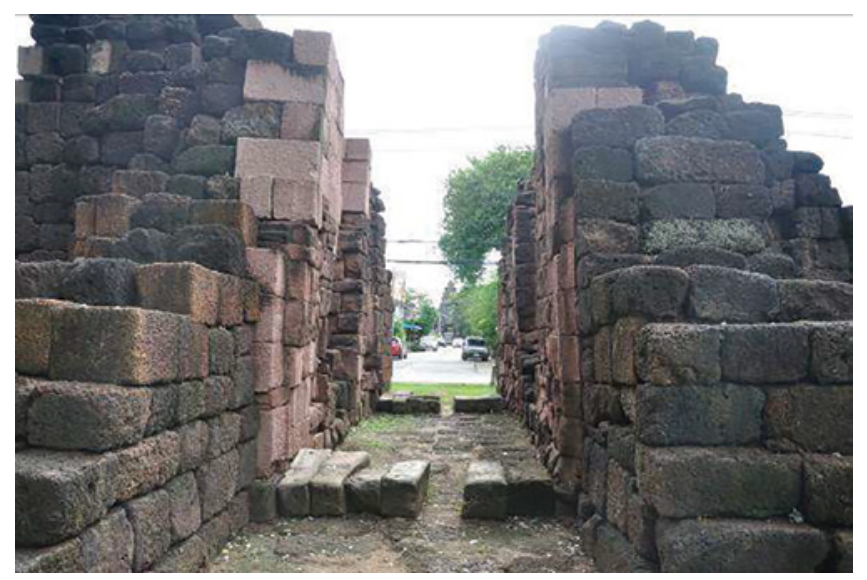

FIGURE 18 Stone jambs of the doors in the West Gate. View from outside the town (author's photo, 2017)

represent the guardian bodhisattva Avalokitesvara looking towards the four cardinal directions, protector of the cities and the kingdom (Jessup 2004, 173), and both Kings Jayavarman VI and Jayavarman VII (with one hundred years difference and related to Vimayapura) are known for ordering the construction of Buddhist monuments. In the case of the second, he is famous for 
his special predilection for that iconographic way of decorating city gates and temples (Albanese 2005, 132-33, 220-35; 2006, 202-19; Freeman and Jacques 2008, 74-83).

\section{5}

\section{The Defence of the Fortified Walls}

The first impression we get of its potential capacity for resistance against external attack is that the city enceinte of Vimayapura was not very strong, except for the gateways. On the one hand, with a width of around one metre in the central part, the laterite curtain walls are very narrow, especially in comparison with ancient Indian fortresses, which were always bulky (Deloche 2007). On the other hand, a total height of around 4 metres is not very impressive, although not inconsiderable. After all, not many Khmer city walls were thicker and taller than this.

Following the general characteristic of the Khmer enceintes from the Angkor period, in the city wall of Vimayapura there were no types of towers, a military structure which could provide much more strength to the defended position. Neither bastions nor advanced forts were built. Moreover, unlike in medieval Europe and the Middle East, arrow loops were not used and no allures — a raised protected walkway behind a battlement or parapet - were constructed to facilitate defenders shooting arrows or throwing javelins from the top of the walls.

In respect of possible attackers, Cham, Burmese and Tai, like Khmer soldiers, were armed mainly with lances and bucklers, bows and arrows, axes, sabres, swords, daggers and knives (Charney 2004a; Jacq-Hergoualc'h 2007, 1326; Quaritch-Wales 1952). Either a wall of stone, laterite, earth or a wooden palisade was sufficient protection against these weapons, if designed to be strong and defended actively by an appropriate number of urban guards and military troops. No firearms were deployed by the Khmer armies or their enemies at the peak of its empire when the walls and city of Phimai were constructed and used. ${ }^{27}$ Except for long ladders, rudimentary rams, a few ballistas

27 Firearms were sent from Ming China to the different kingdoms of the Indochinese Peninsula mainly at the beginning of the $15^{\text {th }}$ century, when they "affected every area of warfare in the region, from stockades to raiding, river warfare to sea combat, and fortress sieges to field battles" (Sun 2003, 3, 495-517). It was at that moment, for instance, when the massive city walls of Sisatchanalai and Kamphaeng Phet were built, adapted to resist the new artillery. 
and other simple war machines, ${ }^{28}$ they did not count on massive and technically advanced siege engines.

War elephants were the main striking force of Southeast Asian armies from the first century AD, often used on battlefields, in duels of the military nobility and assaults on fortifications (Nossov 2008, 32-37; Schliesinger 2012). Not only could they carry several armed soldiers, artillery and battering rams for breaking into walled enceintes they were also renowned for their ability to "destroy ramparts, gates and towers" and "crush forts and encampments" (Arthashastra XI.iii, 2.2.13, 14 and 10.4.14; Kautilya 1992, 657-58).

With an average shoulder height of 2.5 (females) and 2.75 metres (males), the Asian elephant is smaller than the African elephant. ${ }^{29}$ If we estimate that in Cambodia and Thailand they are between 2 and 3.5 metres tall at shoulder and we add one metre more for the size of a soldier sitting astride on top, counting the trunk and the arms extended upwards, this means that the top of a 3-4.5 metres high wall could be reached by the weapons of mounted enemies and climbed on to directly from the backs of elephants, depending on the size of each animal and other factors. ${ }^{30}$

In the Khmer empire, the only defensive walls higher than this "security height" of more than 5 metres are found in the capital, Angkor Thom. Actually, its 8-metre high enceinte is perfectly appropriate for one of the biggest and most populated cities of the world during the $12^{\text {th }}$ and $13^{\text {th }}$ centuries (Pérez 2016b, 239-40). The walls of Vimayapura were at least half high than those from Angkor Thom. An assumed total height of around 4 metres could indeed provide some security against elephant attacks, if they were not very big, but they could not guarantee it $100 \%$ due its size limitations. ${ }^{31}$ Moreover, the walls in most of the rectilinear sections were very narrow, another weak point in the overall military strategy. Only in the gates were the height and width of the fortified structures sufficient to resist better assaults of elephants, together

28 The relief of the Bayon, in Angkor Thom, depicts a war machine composed as a wheeled chart with lancers standing behind two long shields or bucklers (Jacq-Hergoualc'h 2007, 36-37).

29 The native subspecies from mainland Southeast Asia is the Indian elephant (Elephas maximus indicus).

30 This number could be even higher if an elephant seat (howdah) was used and the warriors stood up on it, as some of the stone reliefs from Angkor Thom depict (JacqHergoualc'h 2007, 61-81). As for the fighting towers, in the Indochinese Peninsula their chronology is from Early Modern period, although they had been used in India since the medieval period.

31 Ancient Indian authors explain that elephants could pull merlons off a wall with their trunks or they served as live battering rams to attack fortified gates (Nossov 2008, 12). 
with the double gate system and the use of thick doors of wood reinforced with metal spikes.

Because of this, the passive defences of the city required strong combination with active defences - arrows and throwing spears - in case of external threat. And even so, we think they might not have been effective enough on occasions. Finally, we have to consider an additional weapon that could increase the level of vulnerability of the walls of Vimayapura even more: the Southeast Asian ballista. Although the double-bow crossbows had long been invented in China (Turnbull 2001, 12-15), the Cham and Khmer armies adopted them during the $12^{\text {th }}$ century and managed to put them on elephant back, as well as on two-wheeled carriages. ${ }^{32}$

Moats

Vimayapura was surrounded by the path of Mun River to the north and part of the east side and its tributary, the wide Chakarat River, that runs in a straight line parallel to the west side and Khem River at around one kilometre to the south of the city walls, in the place where the Khmers dug a giant pond or water reservoir (Sa Plaeng Baray). This convenient and privileged location provided the city with a first defensive line. Using natural watercourses as moats was a way to save time, economic resources and human effort in excavating ditches. Nevertheless, the weak point of this military technique was the fact that potential enemies could also use the navigable rivers to easily reach the immediate environs of the city by boat. Thus, its major strength could become also its vulnerability. ${ }^{33}$

Anyway, Vimayapura counted on the additional protection of artificial moats, filled with water ${ }^{34}$ and strategically placed between the stone enceinte and the rivers. Sections of moats have been found in the north (Figure 19) and

32 Reliefs at the temples of Bayon (Angkor Thom) and Banteay Chmar depict four types of ballistae on Cham and Khmer war elephants (Jacq-Hergoualc'h 2007, 28-35; Mus 1929, 331-41; Sharrock 2015).

33 This is the case with the Thai city of Ayutthaya (1351-1767), for instance, which was completely surrounded by canals connected to the Chao Phraya River, resulting in a fluvial island frequented by ships from the whole world (Garnier 2004). However, Ayutthaya had cannons for its defence. Although some authors) have described the location of Phimai as an "almost natural island" (Freeman 1998, 72), Mun River and its narrow tributaries are not as easily navigable as Chao Phraya. Moreover, between the streams and the city walls there were artificial moats as additional obstacles.

34 Although during the dry season some moats in Cambodia and Thailand could experience a decrease in the level of water and even became temporarily dry, they continued being 


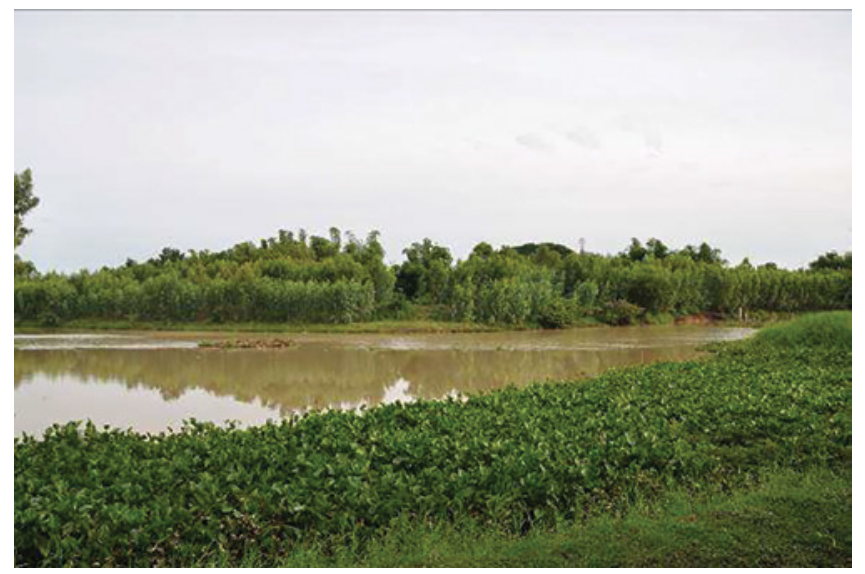

FIGURE 19 The moat on the north side of the town (author's photo, 2017)

north-west of the city (Figure 20). Moreover, in aerial and satellite photographs, as well as in field observations, a sort of rectilinear canal can be distinguished in the north-east side of the enceinte, just in front of the place where the city walls once stood, with a width similar to the west moat. This leads us to identify it with the north-west section of the ancient moat system of Vimayapura.

On the west side the moat has an approximate width of 15 metres (measured between the West Gate and the north-west angle of the enceinte), while it is superior on the north side (15-20 metres) and slightly inferior to the east. Their lengths are the same as the original north side of the walls ( 565 metres) and less than half of the west and east sides (circa 515 metres). In the centre of the west side, immediately after the end of the moat, there is a small ancient pond (Sa Bohd Baray) that lengthens the sections of the walls protected by artificial water obstacles. ${ }^{35}$

The north and east moats are connected to the Mun River, thus always remaining full of water, both in the wet and dry seasons. However, nowadays the course of the moats is interrupted by several narrow transverse embankments,

effective anyway, especially in combination with walls or earthen embankments crowned with palisades.

35 In 1901, Aymonier estimated that the city of Vimayapura originally had three sides completely protected by moats (north, south and west) and in the East, an artificial moat was not excavated because the course of Mon River served as a natural moat (Aymonier 1901, 119 and 121, Fig. 18). According to him, they were 100-metre wide, which seems an exaggerated size only found in Angkor Thom. We suppose the reason for this confusion could be the misinterpretation of moats for the water reservoirs (barays) that he found near the external perimeter of the city. 


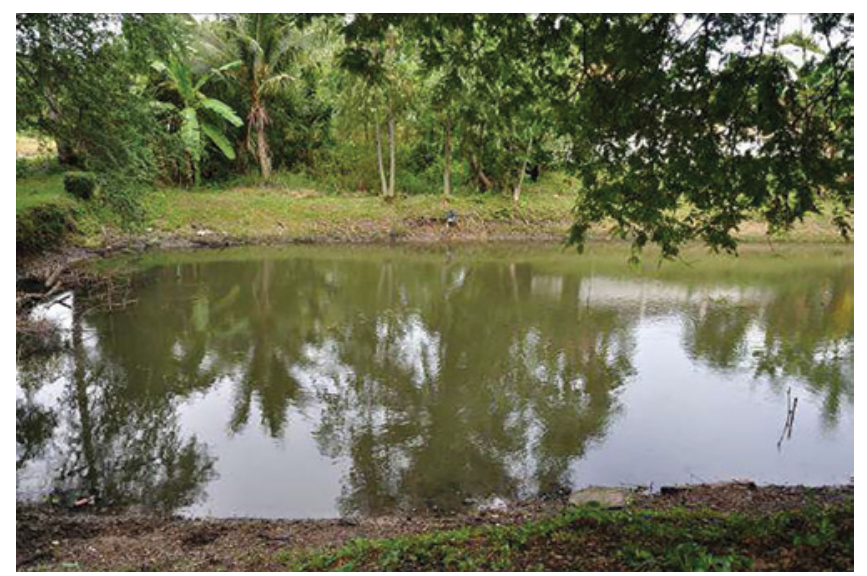

FIGURE 20 The moat on the west side of the town (author's photo, 2017)

as high as the level of the circulation of cars, constructed by the modern inhabitants to allow the traffic between the inner and outer part of the ancient city centre. Although in the present time, there are no remains of wet moats in the southern half of the city, for design coherence and comparison with other Khmer moated towns we suppose that these were originally excavated also in the south, south-east and south-west, forming a complete rectangle. In the last few centuries, especially with the obsolescence of the walls and moats, they were filled with soil and houses were built on them. ${ }^{36}$

As for the width of the moat, we consider that $15^{-20}$ metres was sufficient for protecting the city, as this size is not much different from other cases in Thailand, although inferior to the average Khmer regional capitals. Thus, the moat of the Khmer provincial city Beng Mealea is 45-metre wide (Freeman and Jacques 2008, 220), which is double or nearly triple the one from Vimayapura. A visual analysis of satellite maps also reveals that the city moats of Banteay Chmar and Preah Khan of Kompong Svay were also wider. However, as we can observe personally in situ, the width of Phimai is similar to the $14^{\text {th }}-15^{\text {th }}$ century Thai moats of Sukhothai, Sisatchanalai and Kamphaeng Phet.

The ancient Khmers developed advanced hydraulic engineering. Excavating moats was not a difficult task for them, considering their experience in constructing giant water reservoirs and canals. Moats were an indispensable element not only in Khmer cities but in all Mainland South-East Asian cities in

$3^{6}$ We hope future archaeological excavations can be carried out in this area, so not only they may confirm this hypothesis but also date more precisely the excavation of the moats and maybe even the construction of the walls. 
general, starting from the example of the imperial capital in Angkor and its extraordinary 100-metre wide and 6-metre deep moat. ${ }^{37}$ Moats could indeed provide a more effective protection against enemies than walls and, in general, excavating them was technically easier and even cheaper than building a solid wall. In our opinion, they could stop an army of elephants even better that the walls themselves, especially if we consider the moderate height and scarce width of the fortified enceinte of Vimayapura.

A water-filled moat of more than $2-3$ metres in depth would have impeded war elephants crossing it simply by walking. It is true that elephants can swim but it is more complicated swimming with a heavy load on their backs -a mahout, one or more soldiers with their weapons and combat clothes, possibly a howdah and maybe artillery. ${ }^{38}$ Moreover, both in cases where they tried to swim across a moat when it was deep or filled to full capacity or in cases where they could walk across it when the level of water was lower during the dry season, in that slow moment an army of war elephants was highly vulnerable to an attack by arrows and javelins thrown from the top of the nearby walls. The same applies to the cavalry ${ }^{39}$ and foot soldiers that became an easy target for the defenders if they swam and also if they used canoes or simple rowing boats.

There were many factors in a moat that could slow or even hinder the progress of war elephants, cavalry or infantry, including the water, unstable muddy bottoms, pinned stakes and the inclination of the slopes. In any case, it seems that military leaders found it easier to attack a moated settlement during the dry season. ${ }^{40}$ In South East Asia, the monsoon conditioned the war movements of ground troops and also gave a preponderant role to river warfare. Many sieges were suspended when the monsoon began, due to the risk to the besieging force: as most major towns were located along rivers and in flood

37 Before the construction of the massive moat of Angkor Thom at the end of the $12^{\text {th }} \mathrm{c}$. (Albanese 2005, 221-23; 2006, 200-01), it is not clear that the previous royal capital Yashodharapura had a moat of 200-metre wide, as it was thought during the $20^{\text {th }} \mathrm{c}$. (Pottier 2000, 79-107).

38 A few centuries BC, the Indian writer Kautilya described in the Sanskrit Arthashastra treatise the functions of elephants in war. One of them was "helping to cross water and climb or descend from mountains" (Arthashastra XI.iii, 10.4.14; Kautilya 1992, 659). Although they could help an army with its cargo to cross a river or moat, we may suppose they were more useful in cases where the stream was not wide neither too deep to force them to swim. Moreover, if they were used to cross a moat while being attacked directly by the defenders of the stronghold, we can assume a high level of casualties.

39 Although cavalry was less numerous and important than war elephants units, Southeast Asian armies like the Khmer or their Thai enemies also included some war horses and chariots (Jacq-Hergoualc'h 2007, 40-60).

$\mathrm{A} 7^{\text {th }}$ century inscription of the king of Chenla Jayavarman I notes that he went to war in autumn, when his enemy's moats were dry (Higham 2002, 207). 
plains, it is also probable that the surrounding land became flooded. Since roads and bridges were washed out, travel across the country was difficult and the attackers could not maintain supply lines or back-up communications and diseases could debilitate an army exposed to temporary shelter (Charney 2004, 78).

Besides their practical function as a passive defence and probably also as a source for irrigating fields, ${ }^{41}$ moats as well as water reservoirs (barays) could also be interpreted as a representation of the cosmic Ocean of Milk from Hindu cosmology, the Sea of Creation surrounding Mount Meru (Mabbett 1983, $64-83)$. This idea is suggested by the fact that not only cities but also the successive enclosures of Khmer temples were often also surrounded by moats and included small ponds within their limits. This brings us to the importance and symbolism of water in the Khmer civilisation, often defined as urban and hydraulic. ${ }^{42}$ And, consequently, the efforts of political powers to control it. ${ }^{43}$

\section{Discussion and Conclusion}

As in any other culture or civilisation, the defence of a city consisted of a combination of both passive (walls, earthworks, ditches) and active (soldiers) components. However, the city walls that the Khmers introduced in the region of the Mun River were totally different from their Mon predecessors, although they were also an Indianised culture. The towns of the Iron Age (500 BC-500 $\mathrm{AD})$ and the historical Dvaravati period (500-1000) were built by the Mon people without a rigid preconceived urban plan. They had a circular shape instead of rectangular and they were surrounded by earthen embankments instead of by stone walls. In addition, they were encircled by a successive series of concentric moats (one, two or three), which were also circular (Moore 1988; O'Reilly 2015, 9-18).

From the study of the archaeological remains, we are tempted to think that during the Classical Khmer period very few walls were constructed and this may suppose that their cities lacked any type of defence. However, it is difficult

41 Since the mid-first millennium BC, moats surrounding towns in present day Thailand and Cambodia could provide water for both agriculture and domestic use during the dry season (Higham 1996, 33).

42 The megalomania of Khmer kings could only have started because of despotism linked to mastery of water resources (Groslier 1979, 161-202).

43 In the specific case of the Khorat plateau, it is a relatively arid land where irrigation is essential; therefore, water was probably identified with power (Dumarçay and Royère 2001, XXIII). 
to imagine important centres of power being totally unprotected, even at a moment of relative internal peace propitiated by the Khmer military hegemony in the peninsula. We should better consider that, as well as the existence of soldiers, their cities were surrounded at least by moats, by laterite and sandstone blocks in prestigious citadels and/or possibly by embankments (earth ramparts) and wood structures.

Chou Ta Kuan, ${ }^{44}$ a Chinese who travelled to Angkor and the Khmer empire in the $13^{\text {th }}$ century, explains that "in each provincial city there was a fortified citadel" (Zhou 2007, part 33). The fact that in some cases there are no remains left of solid walls - made of stone, laterite or bricks - does not necessarily mean the absence of any type of enceinte, because the same author also informs us of the use of palisades to protect the regional capitals. What we do not know for sure is whether they only were raised around the citadel — which is highly probable - or whether they also included the urban periphery, the extended city space where common citizens often lived. In any case, the erection of stockades for defensive purposes was widespread across all South-East Asia from the Bronze-Iron Age. Although this material was perishable, it had several advantages: its low cost, speed of construction, easy availability and practically unlimited potential size (Charney 2004, 87-90).

We would define the type of Khmer urbanism as dispersed habitat around monumental centres, with a large number of the population living in great extensions of land outside the city walls or moats. This leads us to consider the walled enceintes of Khmer settlements not as whole cities but merely as citadels, as the political and religious centres of each city, the seats of regional and imperial power which needed to be more protected, monumentalised with non-perishable materials and symbolically separated from the commoners. Thus, many inhabitants lived outside the enceinte of Vimayapura, in the same way that also happened outside the walls of Angkor Thom.

Some authors (Pottier 2000, 79-107) have stated that several early Khmer urban centres would have been open cities, devoid of enclosures, mentioning as examples Hariharalaya (Roluos), Yashodharapura I (Angkor) and Chok Gargyar (Koh Ker) (Stuart-Fox and Reeve 2011, 114-115). That is because they interpreted most of the remains of embankments dated between the $8^{\text {th }}$ and $11^{\text {th }}$ centuries not as urban enceintes but merely as dikes to contain water. Other authors, however, think that cities like Yashodharapura should have been protected by a laterite fortification topping an embankment, although nothing remains of it (Stuart-Fox and Reeve 2011, 114-15). In our opinion, if Yashodharapura did not have any defensive laterite perimeter, at least it was surrounded 
by an earthen wall crowned with a defensive palisade. However, this was not enough to prevent an immense Cham army from sacking the imperial capital in 1177 .

Also, Vimayapura since its beginnings should have been provided with an appropriate embankment, a stockade and a perimeter moat, in accordance with the technical innovations brought to the region by the Khmers. Some decades before its foundation, Suryavarman I (1010-1050) was said to have been the first Khmer king to have introduced rectangular moated and walled sites in the Khorat Plateau or Upper Mun River Valley, besides rectangular enclosure and large rectangular barays (Welch 1997, 74; 1998, 208; Evans 2015, 97).

In any case, in comparison with other countries and historical periods, it is true that most habitation sites during the Angkorian period did not have any defensive architecture. This is also the case of the Phimai region that was, with the integration into the Khmer state, a strong political entity which guaranteed the internal security with local farmers moving from large villages protected by moats and walls to small exposed hamlets (Welch 1997, 76). Then, those defence structures increased their size and adopted a rectilinear plan but became reserved for the rectangular citadels of major Khmer urban centres, like Vimayapura. And at the same time, since the Khmer Empire was at its peak and counted on an effective army there was no need to focus on the construction of strong fortresses (Hendrickson 2007, 111-12). Hence, the symbolic role of the urban enceintes was for prestige. After all, they strongly believed in the symbolic protection of the city with an apotropaic character provided by their sacred temples.

Urban enclosures from any part of the world rarely had a single aim, purely military or exclusively symbolic. In general, city walls would have had several functions at the same time, with a major or lesser role depending on different factors, which may have varied through history. In the case of the Khmer civilisation these were: 1) city defence, 2) urban prestige, 3) symbolic representation of the Hindu cosmology and, why not, 4) control of the passage of people and trading goods through the gates.

Amongst the architectural elements from the enclosure of Vimayapura which were more ornamental than military we can mention the basement, cornice and possibly also the disappeared row of pinnacles that could have crowned the walls. Moreover, there are other factors that make us think the enceinte was not designed very strongly, such as its narrow size and moderate height, except for the gates.

The city walls of Vimayapura were designed to resist neither the attack of big war machines nor siege engines, uncommon in South-East Asia, nor cannons, non-existent before the $15^{\text {th }}$ century. At the peak of its empire, Khmer 
armies preferred to stop the advance of enemies before they reached any city. On the other hand, further to the east, in the upper Chao Phraya basin, the thick walls of Sisatchanalai and Kamphaeng Phet (Thailand) are, in our opinion, good examples of city fortresses designed with a strong military purpose, well prepared to resist sieges. However, they were built by the Tais during the decline of the Khmer empire, at the beginning of the $15^{\text {th }}$ century, in an unstable border region which was susceptible to attack from the Burmese kingdom. In addition, they integrated technical innovations and adaptation to firearms. Military needs had changed.

However, Vimayapura was provided with artificial moats and perimeter rivers which could provide the city with major isolation and resistance to hypothetical attacks in case of emergency. Moreover, the gateways were quite strongly fortified according to the standards of South-East Asian military architecture. Therefore, the defensive system around this provincial urban centre as a whole may not have been merely decorative or symbolic (in theory) but in practice it could have played these non-military roles in a predominant way and for most of the time be of use. Indeed, there was no need for it for centuries, due to the internal security perception granted by the external military successes of the hegemonial Khmer armies at the height of its empire. That is why the unexpected incursion of the Cham troops up to the capital itself, caused such a serious shock that led the king to promote the reconstruction of many previous earth walls and wooden palisades into more solid materials (stone and laterite), at least in Angkor and the most important provincial centres, probably including also Vimayapura. ${ }^{45}$

Unfortunately, no preserved inscription or historical account mention any battle fought in front of its walls; actually, they do not even talk about the stone enceinte, the ditches or earthworks. Therefore, we do not have detailed information provided by the scant primary sources about military events, such as assaults or sieges. We cannot know whether they took place or whether the walls and ditches were ever forced to play any role beyond their symbolic function.

Moreover, the same as happened in other Khmer cities of the studied period, we also do not have material evidence recovered in excavations around the walls such as weapons that can inform us about the soldiers in Vimayapura (where were they? how many? which was their specific role?). This is another

45 Nevertheless, other authors (Pottier 2000, 66) think that such military events marked the introduction of massive defensive systems in the heart of the Khmer kingdom, for the first time, rejecting the idea of previous earth walls, moats and palisades. We disagree with this opinion. 
difficulty for reconstructing the past. In fact, we should highlight the need for archaeological diggings along the perimeter of the city as well as in the ancient Khmer urban area, although they may not be as attractive to investigate as the interior of the temple grounds, due to the scarcity of remains.

As a conclusion, it seems that in their origins the city walls of Vimayapura were constructed with mainly symbolic and ritual functions (the same as other Khmer provincial counterparts of the time).The stone walls (thin, short and devoid of towers) were, in general, not designed to efficiently resist military attacks. However, they had strong and high gates, in addition to external moats, and we do not know for sure whether there also could have been embankments and palisades (as a $13^{\text {th }} \mathrm{c}$. writer explains about provincial capitals). Therefore, in case of real military attacks, we suppose the army would have been the first line of defence of the city (as was common in the Khmer empire) and the moat the second line (although this one probably also played a symbolic role and another practical function as an irrigation canal or reservoir).

\section{References}

Albanese, Marilia. 2005. Angkor. Barcelona: Folio.

Albanese, Marilia. 2006. Los tesoros de Angkor. Madrid: Libsa.

Aymonier, Etienne. 1901. La Cambodge II. Les provinces siamoises. Paris: Leroux.

Boisselier, Jean. 1952. "Bĕn Mãlã et la chronologie des monuments du style d'Ankor Vat." Bulletin de l'Ecole française d'Extrême-Orient 46 (1): 187-226.

Charney, Michael W. 2004. Southeast Asian Warfare, 1300-19oo. Handbook of Oriental Studies. Leiden: Brill.

Chihara, Daigoro. 1996. "Hindu-Buddhist Architecture in Southeast Asia." Studies in Asian Art and Archaeology 19. Leiden: Brill.

Coe, Michael D. 2003. Angkor and the Khmer Civilization. Thames and Hudson, London.

Crocker, John Victor. 2006. Imagined Pasts. Anastylosis and the Creation of the National Past. Master Thesis. Canberra: Australian National University.

Dagens, Bruno. 2003. Les Khmers. Guide Belles Lettres des Civilisations 10. Paris: Les Belles Lettres.

Deloche, Jean. 2007. Studies on Fortification in India. Collection Indologie 104. Paris: École française d'Extrême-Orient.

Dumarçay, Jacques, and Pascal Royère. 2001. Cambodian Architecture. Eight to Thirteenth Centuries. Leiden: Brill.

Evans, Caitlin Violet. 2015. Sites, Survey and Ceramics: A gIs-Based Approach to Modelling Ancient Settlement Patterns in the Upper Mun River, Northeast Thailand. Ph. Doctor Thesis. Queensland: James Cook University. 
Evans, Damian. 2010. "The Archaeological Landscape of Koh Ker, Northwest Cambodia." Bulletin de l'Ecole Française d'Extrême-Orient 97-98: 91-150.

Evans, Damian. 2016. "Airborne Laser Scanning as a Method for Exploring Long-Term Socio-Ecological Dynamics in Cambodia." Journal of Archaeological Science 74: 164-75.

Ewington, Gabrielle. 2008. Yaśodharapura to Yaśodharapura: Mobility, Rupture And Continuity in the Khmer World. Bachelor Thesis. Sydney: University of Sydney.

Foucher, A. 1903. "Nouvelles et mélanges. Crítique de E. Lunet de Lajonquière, 1902, Inventaire descriptif des monuments du Cambodge." Journal Asiatique 10: 174-80.

Freeman, Michael. 1997. Phimai: Prasat Phiman. Bangkok: River Book.

Freeman, Michael. 1998. A Guide to Khmer Temples in Thailand and Laos. New York: Weatherhill.

Freeman, Michael, Donald Stadtner, and Claude Jacques. 2006. Lanna, Thailand's Northern Kingdom. Bangkok: River Books.

Freeman, Michael, and Claude Jacques. 2008. Ancient Angkor. Books Guides. Bangkok: River Books.

Garnier, Derick. 2004. Ayutthaya. Venice of the East. Bangkok: River Books.

Groslier, Bernard Philippe. 1979. "La cité hydraulique angkorienne; exploitation ou sur exploitation du sol." Bulletin de l'Ecole Française d'Extrême-Orient 66: 161-202.

Hall, Tegan, Dan Penny, Mitch Hendrickson, Colin Cooke, and Quan Hua. 2016. "Iron and Fire: Geoarchaeological History of a Khmer Peripheral Centre During the Decline of the Angkorian Empire, Cambodia." Journal of Archaeological Science: Reports 6: 53-63.

Hendrickson, Mitch. 2007. Arteries of Empire: An Operational Study of Transport and Communication in Angkorian Southeast Asia $\left(9^{\text {th }}\right.$ to $15^{\text {th }}$ centuries CE), Doctor Thesis, Sydney: University of Sydney.

Hendrickson, Mitch. 2010a. "Historic Routes to Angkor: Development of the Khmer Road System (Ninth to Thirteenth Centuries AD) in Mainland Southeast Asia." Antiquity 84 (324): 480-496.

Hendrickson, Mitch. 2010b. "La Voie Royale étail-elle dallée? Re-appraising a Myth of the Angkorian Period Road System ( $9^{\text {th }}$ to $15^{\text {th }}$ centuries AD)." Aséanie 25: 83-119.

Hendrickson, Mitch, Dan Penny, and T. Oliver Pryce. 2010. Industries of Angkor Project: Preah Khan of Kompong Svay (Bakan). December 2009 field Campaign Report. Sydney: Sydney University.

Hendrickson, Mitch, and Damian Evans. 2015. "Reimagining the City of Fire and Iron: A Landscape Archaeology of the Angkor-period Industrial Complex of Preah Khan of Kompong Svay, Cambodia (ca. $9^{\text {th }}$ to $13^{\text {th }}$ centuries A.D.)." Journal of Field Archaeology 40 (6): 644-664.

Higham, Charles. 1996. "A Review of Archaeology in Mainland Southeast Asia." Journal of Archaeological Research 4: 3-49. 
Higham, Charles. 2002. Early Cultures of Mainland Southeast Asia. Bangkok: River Books.

Higham, Charles. 2003. The Civilization of Angkor. London: Phoenix.

Higham, Charles, and Rachanie Thosarat. 2012. Early Thailand. From Prehistory to Sukhothai. Bangkok: River Books.

Hirotomi, Jun, Chantanee Chiranthanut, and Shuji Funo. 2009. "Pimāi (Isān, Tai) no Gairo Taikei to Gaiku Kōsei ni Kansuru Kōsatsu (Considerations on Street System and Formation of Street Blocks of Phimai, Isan, Thailand)." Journal of Architecture and Planning 74 (645): 2399-2405.

Iyemori, Toshihiko et al. 2011. "Geomagnetism and the Orientation of Temples in Thailand." Journal of the Siam Society 99: 139-49.

Jacq-Hergoualc'h, Michel. 2007. The Armies of Angkor. Military Structure and Weaponry of the Khmers. Bangkok: Orchid Press.

Jacques, Claude, and Philippe Lafond. 2004. L'empire Khmer. Cités et sanctuaires VeXIII e siècles. Paris: Fayard.

Jacques, Claude, and Philippe Lafond. 2007. The Khmer Empire. Cities and Sanctuaries, from the Fifth to the Thirteenth Century. Bangkok: River Books.

Jessup, Helen Ibbitson. 2004. Art and Architecture of Cambodia. London, Thames and Hudson.

Kautilya. 1992. The Arthashastra. London-New Delhi: Penguin.

Kulke, Hermann et al. 2009. Nagapattinam to Suvarnadwipa. Reflections on the Chola Naval Expeditions to Southeast Asia, Singapore: Institute of Southeast Asian Studies.

Lunet de Lajonquière, Étienne. 1907. Inventaire descriptif des monuments du Cambodge. vol. 2. Paris: Ernest Leroux.

Mabbett, I. W. 1983. The Symbolism of Mount Meru, History of Religions 23 (1): 64-83.

Magli, Giulio. 2017. "Archaeoastronomy in the Khmer Heartland." Studies in Digital Heritage 1 (1): 1-17.

Manavit, Chanya, and Raviwan Sangwan. n.d. Nam Chom Uthayanprawattisat Phimai (A Guide to Phimai Historical Park). Bangkok: Fine Arts Department.

Mauger, Henry. 1939. "Práh Khẵn de Kốmpon Svày." Bulletin de l'Ecole Française d'Extrême-Orient 39: 197-220.

Miksic, John Norman, and Geok Yian Goh. 2017. Ancient Southeast Asia. London-New York, Routledge.

Mollerup, Asger. 2012. Ancient Khmer Sites in Eastern Thailand. Bangkok: White Lotus.

Moore, Elisabeth H. 1988. Moated Sites in Early North East Thailand. Oxford: British Archaeological Reports International Series 400.

Mus, Paul. 1929. "Les balistes du Bàyon." Bulletin de l'École Française d'Extrême-Orient 29: $331-341$.

Nossov, Konstantin S. 2008. War Elephants. Oxford: Osprey Publishing. 
O'Reilly, Dougald. 2015. "Moated Sites of the Iron Age in the Mun River Valley, Thailand: New Discoveries using Google Earth." Archaeological Research in Asia 3: 9-18.

Patra, Benudha. 2007. "Jaugada. An Early Historical Fort Town of Orissa." Orissa Review, 63 (6, January): 44-47.

Pérez Garcia, Víctor Lluís. 2016a. "La difusión de la planta urbana ortogonal china en los siglos VI-VIII: Corea y Japón (The Spread of Chinese Urban Grid Plan in the $6^{\text {th }}$ and $8^{\text {th }}$ Centuries: Korean and Japan)." ArqueoWeb 17: 1-23. Universidad Complutense de Madrid.

Pérez Garcia, Víctor Lluís. 2016b. "South-East Asian Fortified Stone Walls: Angkor Thom (Cambodia), Ho citadel (Vietnam) and Ratu Boko (Indonesia)." Humaniora.Journal of Culture, Literature and Linguistics 28 (3): 238-253.

Phuong, Tran Ky. 2012. Vestiges of Champa Civilization. Hanoi: The Gioi Publishers.

Pichard, Pierre. 1976. Pimay. Étude Architecturale du Temple. Paris: Ecole Française d'Extrême-Orient.

Pottier, Christophe. 2000. "À la Recherche de Goloupura." Bulletin de l'Ecole française d'Extrême-Orient 87 (1): 79-107.

Quaritch-Wales, and Horace Geoffrey. 1952. Ancient South-East Asian Warfare. London: Bernard Quaritch.

Rooney, Dawn F. 2008. Ancient Sukhothai. Thailand's Cultural Heritage. Bangkok: River Books.

Schliesinger, Joachim. 2012. Elephants in Thailand. Vol. 2. Through the Ages. Bangkok: White Lotus.

Seidenfaden, E. 1923. "An Excursion to Phimai, a Temple City in the Khorat Province." Journal of the Siam Society 17 (1): 1-19. Bangkok.

Sharrock, Peter D. 2015. Banteay Chmar. Garrison Temple of the Khmer Empire. Bangkok: River Books.

Stuart-Fox, Martin, and Paul Reeve. 2011. "Symbolism in City Planning in Cambodia from Angkor to Phnom Penh." Journal of the Siam Society 99: 105-38.

Sun, Laichen. 2003. "Military Technology Transfers from Ming China and the Emergence of Northern Mainland Southeast Asia (c. 1390-1527)." Journal of Southeast Asian Studies 34 (3): 495-517.

Talbot, Sarah, and Chutima Janthed. 2001. "Northeast Thailand before Angkor: Evidence from an Archaeological Excavation at the Prasat Hin Phimai." Asian Perspectives 40 (2): 179-94.

Turnbull, Stephen. 2001. Siege Weapons of the Far East (1) AD 612-13oo, Oxford: Osprey Publishing.

Uchida, E., K. Ito, and N. Shimizu. 2010. "Provenance of the Sandstone used in the Construction of the Khmer Monuments in Thailand." Archaeometry 52 (4): 550-74.

Watsantachad, Nuanlak. 2005. A Study of Laterite used in Khmer Architecture in Thailand, Ph.D. Thesis. York: University of York. 
Welch, David J. 1997. "Archaeological Evidence of Khmer State Political and Economic Organisation." Bulletin of the Indo-Pacific Prehistory Association 16: 69-78.

Welch, David J. 1998. "Archaeology of Northeast Thailand in Relation to the pre-Khmer and Khmer Historical Records." International Journal of Historical Archaeology 2 (3): 205-33.

Yule, Paul, and Wolfgang Böhler. 2004. "Sisupalgarh: An Early Historic Fortress in Coastal Orissa and its Cousins." Beiträge zur allgemeinen und vergleichenden Archäologie 24: 15-29.

Zhou, Daguan. 2007. A Record of Cambodia. The Land and its People. Chiang Mai: Silkworm Books. 